\title{
HYGIENIC ASSESSMENT OF IMPACT ON PUBLIC HEALTH AIR POLLUTION IN VIEW OF THE COMBINED ACTIONS OF CHEMICALS IN THE AREA OF THE CHEMICAL INDUSTRY
}

\author{
L.M. Shevchuk ${ }^{1}$, N.A. Tolkacheva ${ }^{2}$, A.E. Pshegroda ${ }^{1}$, I.P. Semenov ${ }^{2}$ \\ ${ }^{1}$ Republican Unitary Enterprise "Scientific and Practical Center of Hygiene", Republic of Belarus, Minsk, \\ 8 Akademicheskaya St., 220012 \\ ${ }^{2}$ EI "Belarusian State Medical University”, Republic of Belarus, Minsk, 83 Dzerzhinsky Pr., 220016
}

\begin{abstract}
The article presents the results of air pollution study in the area of chemical industry. The results of evaluating possible impact of chemical pollution on the population health are reflected by the parameter values: complex indicator " $R$ " public health risk (reflexive, chronic, and combined risk at the reflexive and chronic action), hazard index and combined action coefficient. The comparative characteristic of the received data is provided by the degree of air pollution during the evaluation, taking into account the combined effect of chemicals and during the evaluation without the combined action of chemicals. The possibility of using the results to predict the changes in the population health status and to plan epidemiological studies is determined.

Key words: atmosphere chemical pollution, combined action of chemicals, combined risk of chemicals, combined action coefficient.
\end{abstract}

Fast growth of cities, construction and reconstruction of industrial enterprises as well as expansion of residential areas at the expense of the land adjacent to the enterprises and other facilities determine the need for the assessment of the cityplanning decisions in terms of its negative impact on public health. Atmospheric air pollution can have a significant effect on the health of local residents $[1,2]$. Air pollution, as reported by the World Health Organization, is the most important individual environmental risk factor for the population of the European Region [3, 4]. Increased atmospheric air pollution (other conditions being equal) results in a 6-7\% increase is cute respiratory infections caused by non-specific influence $[5,6]$.

In order to make town-planning decisions in the future with the account for potential unfavorable effects determined by air pollution, it is also necessary to take into account the multi-component nature of atmospheric air pollution $[5,6,7,8]$.

In the Republic of Belarus, the decision on potential allocation of new facilities in close proximity to residential areas depends to a great extent on the results of the assessment of the health risks associated with the pollutants emitted into the air by the facility. The assessment involves multiple regulatory and technical documents in this area and follows an established procedure. Health risk assessment for city-planning decisions conducted in the Republic of Belarus is an example of collaborative work between environmental agencies and health organizations thus reflecting the strategy and priorities of the World Health Organization [4].

The health risk assessment methodology is used to analyze the city-planning decisions for the existing (reconstructed) and projected facilities with the account for the multi-component nature of air pollution. Risk assessment is also used to plan preventive activates aimed at protecting the public from the unfavorable impact of chemicals emitted by the facility.

Purpose: assess the impact of the atmospheric air pollution on public health with the account for the combined effect of chemicals in the location of a chemical enterprise.

(C) Shevchuk L.M., Tolkacheva N.A., Pshegroda A.E., Semenov I.P., 2015

Shevchuk Larisa Mikhailovna - Candidate of Medicine, Associate Professor, Deputy Director for Research (e-mail: sheuchuklm@mail.ru; tel. +375 17 292-50-15).

Tolkacheva Nadezhda Andreevna - Assistant of the Department of Occupational Health in Educational Institution "Belarusian State Medical University", 83, Dzerzhinsky Pr., Minsk, Republic of Belarus, 220016 (e-mail: gt@bsmu.by; tel. 17375 365-84 -43).

Pshegroda Aleksandr Evgenyevich - Senior Researcher at the Laboratory of Environmental Factors and Health Risk Analysis Technologies (e-mail: risk.factors @ rspch.by; tel. +375 17 292-47-00).

Semenov Igor Pavlovich - Candidate of Medicine, Associate Professor, Head of the Department of Occupational Health (e-mail: gt@ bsmu.by; tel. + 37517 365-84-43). 
Research materials: analysis of the main stages of technological production process; graphic materials on the location of the sources of emission from the main industrial enterprises in the residential areas and the areas that need protection; simulation of the outspread of chemicals emitted by the enterprise in the atmospheric air, and analysis of public health risks associated with these chemicals; results of the in-process supervision of polluted atmospheric air in the area of the enterprise location; background concentrations of chemical pollutants in the area of the enterprise location.

\section{Obtained Results.}

In order to determine the groups of priority chemical pollutants emitted by the industrial entities and to determine the branches of the natural economy that present the biggest hazard in terms of air pollution, we studied the materials of the surveys and risk analysis in 219 residential areas of the Republic of Belarus. Based on the research findings, it was determined that the following chemicals are the biggest air pollutants: nitrogen oxides, carbon monoxide, particulate matter of different fractions, heavy metals (mercury, lead, cadmium) and volatile organic compounds. We identified the fastest growing industries - major contributors to the air pollution in the e residential areas. Subsequent to the results of the analysis, we selected an enterprise specializing in the production of urea-formaldehyde resins, adhesives, paints and other organic substances, located in the town of Borisov in Minsk Region. The enterprise is located in an industrial area of Borisov, a town created by the enterprise, bread-baking complex, meat-processing complex, and a number of other industrial enterprises occupying the total area of 13.1446 hectares. Residential areas are located in close proximity to these enterprises. According to [9], the sanitary protection zone (hereinafter SPZ) of the enterprise is $500 \mathrm{~m}$. It includes:

- To the north - a food-producing plant (bread-baking complex);

- To the East - a waste ground, then a railroad precinct, then another waste ground, and $130-150 \mathrm{~m}$ from the external border of the enterprise $(330-350 \mathrm{~m}$ from the polymeric petroleum resin production facility) - a residential neighborhood down Sennaya Str.

- To the South - industrial facilities;

- To the West - industrial park;

- To the North-West within $200 \mathrm{~m}$ - a residential neighborhood down Stroiteley Str.

- To the South-West - a free-standing residential area down Demina Str. with two residential houses.
The enterprise estate has 232 (organized and non-organized) emission points, gross emission totals 46988 tons per year. These emission points emit 40+ hazardous substances, including class 1 hazard substances $-0.03 \%$ of the gross emission, class 2 hazard substances $-27.39 \%$, class 3 hazard $-9.56 \%$, and class 4 hazard $-62.08 \%$.

To assess the air pollution concentration in the area of location of the enterprise, the following territories were selected: the borders of the enterprise grounds (currently, the SPZ borders), nearby residential area - 130-150 m from the borderline of the enterprise ground and a residential area affected by the enterprise at $210 \mathrm{~m}$ from the enterprise ground.

As a result of the calculation of the chemical dispersion at the border of the production site of the enterprise, at the border of the nearby residential area $(130-150 \mathrm{~m})$ and at the distance of $210 \mathrm{~m}$ from the site border, the maximum concentration of the emitted substances did not exceed the hygienic standards, except for solid particles and formaldehyde (0.89-1 and 1.08-1.1 in fractions of MAC respectively). The average annual concentrations for all the 32 substance did not exceed the hygienic standards. In-sight supervision did not reveal any excess of the hygienic standards.

We conducted an assessment of the air pollution with the use of complex factor $\mathrm{P}$ and complex air pollution index in terms of 5 priority substances (hereinafter-CAPI) - see Table 1.

To assess potential health effects caused by the emitted chemicals, we calculated the health risks associated with the emitted substances. The results of the assessment of health risks associated with clean concentrations of pollutions are shown in Table 2.

To analyze potential unfavorable effects under combined action of chemicals, we used the following indicators: combined risk of chemical action, hazard index, combined action coefficient $[5,10]$.

We calculated the value of combined risk of reflex effects for the whole mix of chemicals emitted by the enterprise, based on the multiplication of probabilities method [11]:

$$
\operatorname{Risk}_{\mathrm{cyM}}=1-\left(1-\text { Risk }_{1}\right)\left(1-\text { Risk }_{2}\right) \ldots \ldots\left(1-\text { Risk }_{\mathrm{n}}\right),
$$

where Risk $\mathrm{cym}_{\mathrm{c}}$ - combined risk of action of a chemical,

Risk $_{1}$, Risk $_{2}$, Risk $_{n}$ - risk of action of each individual substance.

Our calculations were based on the hypothesis that chronic action of the general toxic chemicals at 
low concentrations is characterized by similar nonspecific effects resulting in the necessity of mandatory use in this case of the aggregate risk calculation equation for all the substances in the emission, and has a potential toxic chronic action [11]. For acute action, we used a similar hypothesis.

The values of combined risk are shown in Table 3.

The values of the combined reflex and chronic effects of the full mix are higher as compared to the maximum risks of reflex and chronic effects from one substance from the mix. It is necessary to keep in mind that immediate effects occur in reflex responses among the most sensitive persons, i.e. the persons who are most affected by certain sub- stances prove to be more sensitive to other substances as well. For this reason, potential immediate risk following combined exposure may be equal to the maximum risk of a certain mixture among all the active ingredients, even though it is necessary to take into account total chemical reactivity [11].

To assess total chemical reactivity, we used the combined action coefficient (hereinafterCAC) for the chemical substances that compose the emission from the enterprise $[5,10,12]$.

When assessing the level of air pollution with the use of CAC in the location of the enterprise, we identified 11 summation groups including 4 groups with above-standard CAC values - see Table 4.

Table 1

Air Pollution Concentration in the Location of the Enterprise

\begin{tabular}{|l|c|c|c|}
\hline \multicolumn{1}{|c|}{ Indicator/Area } & $\begin{array}{c}\text { Border } \\
\text { of the Enterprise Site }\end{array}$ & $\begin{array}{c}\text { Residential area (130-150 m } \\
\text { from the enterprise site) }\end{array}$ & $\begin{array}{c}210 \mathrm{~m} \text { from the border } \\
\text { of the enterprise site }\end{array}$ \\
\hline Complex factor P & 2,89 & 2,51 & 2,4 \\
\hline Pollution concentration in terms of P & $\begin{array}{c}\text { Tolerable Pollution } \\
\text { Concentration }\end{array}$ & $\begin{array}{c}\text { Tolerable Pollution } \\
\text { Concentration }\end{array}$ & $\begin{array}{c}\text { Tolerable Pollution } \\
\text { Concentration }\end{array}$ \\
\hline $\mathrm{CAPI}_{5}$ & 3,44 & 2,91 & 2,88 \\
\hline Pollution Concentration in terms of CAPI & low & low & low \\
\hline
\end{tabular}

Health Risks Associated with Clean Concentrations of Pollutions

\begin{tabular}{|l|c|c|c|}
\hline \multicolumn{1}{|c|}{ Indicator/Area } & Border of the Enterprise Site & $\begin{array}{c}\text { Residential area }(130-150 \mathrm{~m} \\
\text { from the enterprise site) }\end{array}$ & $\begin{array}{c}210 \mathrm{~m} \text { from the border } \\
\text { of the enterprise site }\end{array}$ \\
\hline Maximum reflex effect risk & $\begin{array}{c}6,19 \% \text { (for aliphatic } \\
\text { hydrocarbons } \mathrm{C}_{11}-\mathrm{C}_{19} \text { ) }\end{array}$ & $\begin{array}{c}1,04 \% \\
\text { (for carbon monoxide) }\end{array}$ & $\begin{array}{c}1,04 \% \\
\text { (for carbon monoxide) }\end{array}$ \\
\hline Risk characteristics & Satisfactory & Tolerable & Tolerable \\
\hline Maximum chronic effect risk & $\begin{array}{c}5,07 \% \text { (for aliphatic } \\
\text { hydrocarbons } \mathrm{C}_{11}-\mathrm{C}_{19} \text { ) }\end{array}$ & $\begin{array}{c}1,3 \% \text { (for aliphatic } \\
\text { hydrocarbons } \mathrm{C}_{11}-\mathrm{C}_{19} \text { ) }\end{array}$ & $\begin{array}{c}1,11 \% \text { (for aliphatic } \\
\text { series } \mathrm{C}_{11}-\mathrm{C}_{19} \text { ) }\end{array}$ \\
\hline Risk characteristics & Causes concern & Tolerable & Tolerable \\
\hline
\end{tabular}

Table 3

Combined Reflex and Chronic Risk

\begin{tabular}{|l|c|c|c|}
\hline \multicolumn{1}{|c|}{ Indicator/Area } & $\begin{array}{c}\text { Border of the } \\
\text { Enterprise Site }\end{array}$ & $\begin{array}{c}\text { Residential area (130-150 m } \\
\text { from the enterprise site) }\end{array}$ & $\begin{array}{c}210 \mathrm{~m} \text { from the border } \\
\text { of the enterprise site }\end{array}$ \\
\hline The value of combined reflex risk of the full mix & $15,65 \%$ & $2,43 \%$ & $1,69 \%$ \\
\hline Risk characteristics & Satisfactory & Satisfactory & Tolerable \\
\hline The value of combined chronic risk of the full mix & $28,49 \%$ & $14,72 \%$ & $16,18 \%$ \\
\hline Risk characteristics & Hazardous & Causes concern & Hazardous \\
\hline
\end{tabular}

Table 4

CAC for the summation groups of the substances emitted by the enterprise

\begin{tabular}{|c|c|c|c|c|}
\hline Indicator/Area & $\begin{array}{l}\text { Border } \\
\text { of the Enterprise Site }\end{array}$ & $\begin{array}{c}\text { Residential area } \\
\text { (130-150 } \mathrm{m} \text { from the } \\
\text { enterprise site) }\end{array}$ & $\begin{array}{l}210 \mathrm{~m} \text { from the border } \\
\text { of the enterprise site }\end{array}$ & $\begin{array}{l}\text { Standard } \\
\text { value }\end{array}$ \\
\hline Ammonia, hydrogen sulfide, formaldehyde & 1,6 & 1,66 & $-*$ & 1 \\
\hline Ammonia, formaldehyde & 1 & 1,3 & 1,1 & 1 \\
\hline $\begin{array}{l}\text { Nitrogen dioxide, sulfur dioxide, carbon } \\
\text { monoxide, phenol }\end{array}$ & 1,05 & 1,24 & 1,01 & 1 \\
\hline Hydrogen sulfide, formaldehyde & 1,25 & 1,4 & $-*$ & 1 \\
\hline
\end{tabular}

* - dispersion of the substances in the summation group was not calculated (expediency criterion $E<0,001$ ) 
Table 5

Hazard Index Associated with Reflex and Chronic Action of the Substances Emitted by the Facility

\begin{tabular}{|l|c|c|c|c|c|c|}
\hline \multirow{2}{*}{\begin{tabular}{c}
\multirow{2}{*}{$\begin{array}{c}\text { critical organs } \\
\text { and systems }\end{array}$} \\
\cline { 2 - 7 }
\end{tabular}} & \multicolumn{2}{|c|}{ Border of the Enterprise Site } & \multicolumn{2}{c|}{$\begin{array}{c}\text { Residential area } \\
\text { from the enterprise site) }\end{array}$} & \multicolumn{2}{c|}{$\begin{array}{c}210 \mathrm{~m} \text { from the border } \\
\text { of the enterprise site }\end{array}$} \\
\cline { 2 - 7 } & Reflex action & Chronic action & Reflex action & Chronic actio & Reflex action & Chronic actio \\
\hline Respiratory system & 9,27 & 6,34 & 6,67 & 3,33 & 4,8 & 3,61 \\
\hline Central nervous system & 2,9 & 4,82 & 1,32 & 2,22 & 1,18 & 2,60 \\
\hline Mucous & 1,24 & 0,23 & 0,71 & 0,06 & 0,63 & 0,06 \\
\hline Development & 1,22 & 1,23 & 1,05 & 0,84 & 0,94 & 0,92 \\
\hline Immune system & 0,69 & 1,34 & 0,56 & 1,17 & 0,46 & 1,49 \\
\hline Reproductive system & 0,69 & 0,81 & 0,56 & 0,45 & 0,46 & 0,46 \\
\hline Gastrointestinal tract & 0,24 & 0,33 & 0,02 & 0,08 & 0,01 & 0,05 \\
\hline Blood & 0,09 & 1,43 & 0,02 & 1,06 & 0,02 & 1,18 \\
\hline Cardiovascular system & 0 & 1,05 & 0 & 0,73 & 0 & 0,91 \\
\hline
\end{tabular}

For the group of substances emitted by the enterprise, we calculated the hazard index associated with the reflex and chronic action with the account for the critical organs and systems affected by the substances in the mix - see Table 5 [13].

The highest hazard index values (high) were recorded for the respiratory organs at the border of the enterprise site under both reflex and chronic exposure as well as in the residential are under reflex exposure (Table 5).

\section{Conclusion:}

In the Republic of Belarus, the largest amount of emission causing the biggest harm to the environment in terms of air pollution is produced by the following industries: transportation, communication, food, chemical, and agriculture. These are the fastest growing industries. The following substances are prevalent in the composition of the emission: nitrogen oxides, ammonia, sulfur dioxide, carbon monoxide, particulate matter of different fractions, heavy metals (mercury, lead, cadmium) and volatile organic compounds. Composition of the emission and the emitting in- dustries are typical of the overall trends in the republic.

Maximum isolated risks from the emitted substances were recorded for saturated hydrocarbon of the aliphatic series $\mathrm{C}_{11}-\mathrm{C}_{19}$ and are at the level of satisfactory risk under reflex exposure, and causing concern - under chronic exposure. Combined risk from all the emitted substances under reflex exposure is at the level of satisfactory risk, under chronic - at the level "hazard". The obtained high values of the hazard index for the respiratory organs: under chronic exposure -6.34 , under reflex -9.27 .

The obtained results confirm the need to account for the combined action and summation effects of the chemical substances when making cityplanning decisions and changing the sizes of the SPZ which is best realized through risk assessment. The data obtained through risk assessment (the values of combined risk, hazard index, and CAC) also help to reveal potential unfavorable effects on health, identify the areas for further epidemiological research, develop preventative measures to protect public health [14].

\section{References}

1. Air quality and health : WHO Fact sheet $\mathrm{N}^{\circ} 313$, Updated September 2011 [Electronic resource]. - Access mode: http://www.who.int/mediacentre/factsheets/fs313/en/ - Last accessed: 26/12/2013.

2. Zaitseva N.V. Methodological approaches to the assessment of the results and economic efficiency of the risk oriented supervisory activities of Rospotrebnadzor / N.V. Zaitseva, I.V. May, I.V. Shur, D.A. Kiriyanov // Analiz Riska Zdoroviu - 2014 - N N:1.- P.7-9.

3. Environment and health in the WHO European Region: progress, challenges and lessons learned : working document: $65^{\text {th }}$ session Regional Committee for Europe 17.07.2015, №150478 [Electronic resource]. - Access mode: http://www.euro.who.int/ data/assets/pdf file/0018/283041/65wd11e EnvironmentHealth 150478.pdf?ua=1 - Last accessed: 13.08.2015.

4. Progress report on the European Environment and Health Process : working document $: 65^{\text {th }}$ session Regional Committee for Europe 28.07.2015, №150476. [Electronic Resource]. - Access mode: http://www.euro.who.int/_data/assets/pdf_file/0006/283839/65wd18e_EHP_150476.pdf?ua=1 - Last accessed: 13.08.2015.

5. Filonov V.P. Ecological-environmental assessment of health risks associated with the air quality / V.P. Filonov, S.M. Sokolov, T.E. Naumenko. - Mn.: NRANSTEKS, 2001. - 187 p. 
6. Environmental protection in the Republic of Belarus: collection of articles / national Statistics Committee of the Republic of Belarus; [edited: I.A. Kostevich [et al]. - Minsk: [b.i.], 2013. - 255 p.

7. The state of nature in Belarus: environmental bulletin. 2012 г. / Edited by V.F. Loginova. - Minsk, 2013. - 383 p.

8. D. Bard, O. Laurent. Exploring the joint effect of atmospheric pollution and socioeconomic status on selected health outcomes: an overview of the PAISARC project / D. Bard, O. Laurent., L. Filleul, S. Havard, S. Deguen, C. Segala, G. Pedrono, E. Rivi` ere, C. Schillinger, L. Rou“ 11, D. Arveiler and D. Eilstein // Environmental research letters. - 2007. - Vol. 2. - №4.

9. Requirements to the organization of the sanitary protection zones at the enterprises, buildings and other facilities that impact public health and the environment: sanitary standards and rules: approved by the Ministry of health of the Republic of Belarus 15.05.2014, №35. - Introduced on 15.05.2014 [Electronic resource]. - Access mode: http://minzdrav.gov.by/ru/static/acts/tehnicheskie/teksty/obschie_voprosy - Last accessed: 11.05.2015.

10. Pinigin, M. A. Theory and practice of the assessment of the effects associated with the air pollution / M.A. Pinigin // Gigiena i Sanitoriya. - 2001. - N 1. - p. 9-13.

11. Assessment of public health risks associated with the air pollutants: instruction 2.1.6.11-9-29-2004 : approved by the decree of the head State Sanitary Doctor of the Republic of Belarus 05.07.2004, №63. - Intro from 05.07.2004 [Electronic resource]. - Access mode: med.by/methods/pdf/2.1.6.11-9-29-2004.pdf. - Last accessed: 11.05.2015.

12. Hygienic standards for the content of chemical pollutants in the atmospheric air that have the summation effect: hygienic standard approved by the Ministry of Health of the Republic of Belarus 30.03.2015, №33. - Introduced on 30.03.2015 [Electronic resource]. - Access mode: http://minzdrav.gov.by/dadvfiles/000352_158798 gig normativ_33.doc - Last accessed: 11.05.2015.

13. Guidelines on health risk assessment under exposure to chemical pollutants. R 2.1.10.1920-04. - M.: The Federal Center for State Sanitary and Epidemiological Supervision of Russia's Ministry of Health, 2004. - 143 p.

14. The methodology of assessment of health risks associated with environmental factors: guidelines: approved by the Deputy Minister of health of the Republic of Belarus 08.06.2012, рег. №025-1211. - Introduced on 08.06.2012 [Electronic resource]. - Access mode: med.by/methods/pdf/025-1211.pdf - Last accessed: 11.05.2015. 